\title{
Communication Strategy of BKMT Riau Management in the Development of Islamic Da'wah
}

\author{
Arwan $^{1}$, Abdullah $^{2}$, Syukur Kholil ${ }^{2}$ \\ ${ }^{I}$ Ph.D Student in State Islamic University of North Sumatera (UINSU), Medan, Indonesia \\ ${ }^{2}$ Lecturer in State Islamic University of North Sumatera (UINSU), Medan, Indonesia \\ wildanansori22@gmail.com
}

\begin{abstract}
In implementing a communication strategy, a communication plan must include goals, objectives and steps. Likewise, the communication planning of the BKMT Riau Management in the development of Islamic Da'wah in the form of program activities. This study is conducted by using descriptive qualitative approach. The result shows that communication management in the development of Islamic Da'wah of BKMT Riau Management can be traced from the activities program of Da'wah and Issuance of BKMT Riau management for the 2012-2017 period, including planning for organizing, implementing and evaluating. The communication methods used by BKMT are more dominant in informative communication, persuasive communication and educational communication as the most effective and most used method.
\end{abstract}

Keywords: communication strategy; management; Islamic Da'wah; BKMT Riau.

\section{Introduction}

The fact that real history has given testimony to the existence of women who played a large role in delivering Dinul Islam. Sumayyah r.a. gave his life when Abu Jahal killed him because he embraced Islam. He was the first Muslim of a woman who was martyred for the sake of his religion. Khadija ra., Muhammad SAW's first wife, who was very rich, had spent all his money to support da'wah. Umm Salamah ra., willing to leave her husband and see his children being persecuted when he migrated. Ummu Imarah ra., fighting to defend the Prophet Muhammad, in the Uhud War.

Unfortunately studies on the role of women in da'wah activities and Taklim assembly based Muslim Community Empowerment have not been carried out. Even if there is, it is still very limited to the study of their role in the fields of religion, education, politics, and others that are not based on Taklim assembly. One of the socio-religious phenomena that have arisen among Indonesian Muslim communities, is the rise of recitation activities held in various places, mosques and prayer room, especially in the Taklim Assembly. This activity is not only followed by mothers, also fathers, who want to seek religious knowledge directly from the cleric / cleric. The Taklim assemblies are then better and more modernly coordinated through an organized body which has come to be known as the Taklim Assembly Contact Board (BKMT) which was established as a study group for mothers organized through this BKMT activity.

BKMT was first established on the initiative of the late DR. Hj. Tuty Alawiyah AS., on January 1, 1981. The institute sought to bring together the full potential of Taklim Assembly institutions throughout Indonesia. Empowerment of the people through BKMT institutions has become very strategic in the effort to welcome the next millennium. These steps are inseparable from the socio-economic and educational conditions of members of the Taklim Assembly community, the majority of which have a secondary education. Therefore, the agenda for the revitalization of the people must pay attention to the objective conditions of Taklim Assembly members who are members of BKMT. 
At present BKMT has become an organization spread out in almost all regions of the Republic of Indonesia, one of which is the BKMT Regional Management of the Riau Province which was established in 1998 and led by Hj. Roslaini Isma'il Suko. Even though the role and function of the BKMT Regional Administrators of Riau Province are not like other social bodies or organizations in Indonesia, they have a strategic role in nation building and in the efforts of fostering the community, especially women.

\section{Review of Literatures}

\subsection{Communication}

According to M. Bahri Ghazali, communication is an activity carried out by someone to convey a message to another person, so that the person does as intended by the person who conveyed the message. According to Jhon Tondowidjojo, CM., Communication is a process that utilizes certain symbols and codes, carried out between one person / party with another person / party through various ways and levels with the aim that the other party can understand what is adapted by the first party and the opposite.

According to Anwar Arifin, in formulating a communication strategy, in addition to the formulation of clear objectives, it also takes into account public conditions and situations. Meanwhile, according to Onong Unchjana, the communication strategy is defined as "a guide to communication planning with management to achieve the stated goals." Furthermore, according to Onong Unchjana:

The communication strategy consists of two aspects, namely: (1) macro (planned multimedia strategy), and (2) micro (single communication medium strategy). Both aspects have a dual function, namely to disseminate communication messages that are informative, persuasive and instructive systematically to the target to obtain optimal results. Bridging the "cultural gap", for example a program that comes from another cultural product that is considered good to be implemented and belongs to the culture itself depends on how the strategy to package the information.

\subsection{Development of Islamic $\mathrm{Da}^{\prime}$ wah}

The word development means: (1) the process, method, deed of development, for example it is said "the government always strives in the development of gradual and orderly development that leads to the desired target, "(2) language development means" efforts to improve the quality of language so that it can be used for various purposes in the life of modern society, "(3) community development means the process of joint activities carried out by residents of a region to meet their needs.

Language development is a process, a way, an act of developing. While developing itself is to open wide, stretch, make big, make advanced (good, perfect, and so on). According to Morris, in The American Heritage Dictionary of the English Language, it was stated that development is the act of developing. Developing itself contains the meaning "to expand or realize the potentialities of; bring gradually to a fuller, greater, or better state to progress from earlier to later or from simpler to more complex stages of evolution. " bigger, or better, advancing something from earlier to later or from simple to more complex stages of change).

Development is the next management function after we do planning, organizing, motivating, conforming, evaluating, because the next function is developing. This management function appears if the decisions made need to be continued or improved. Because development 
is one of the managerial behaviors that includes training that is used as a means to improve one's skills and facilitate adjustment to work and career advancement, so development becomes an activity that produces a tool or a way to revise something that already exists to be good. As long as the activity is carried out with the intention of making improvements and finally the tool or method is considered good enough to be used so that the development activities end.

\section{Research Methods}

This study belongs to the type of qualitative research, that is "a humanistic research model, which places humans as the main subjects in social / cultural events, or research whose findings are not obtained through statistical procedures or other forms of calculation, such as about life, one's behavior, roles organization, social movements that can be calculated as census data, but the analysis is qualitative."

This research was conducted at the Secretariat of the Taklim Assembly Contact Board (BKMT) in Riau Province, which is located at Jl. Hangtuah An-Nur Great Mosque Housing Pekanbaru, Riau. The time of the study was conducted to 6 (six) months or for 1 semester from the issuance of the research permit.

\section{Discussion}

The application of communication strategy of BKMT Riau management in the development of Islamic $D a^{\prime} w a h$, can be seen from the planning and communication management that have been formulated. The details can be explained as follows:

The communication planning of BKMT Riau management in the development of Islamic Da'wah, can be seen in the activities program of the Da'wah Division and the Issuance of BKMT Riau management for the period 2012-2017, as follows:

1) Revitalizing the function of the mosque / functioning of the mosque as the center of the Taklim Assembly activities in the implementation of Da'wah and Amar Ma'ruf Nahi Munkar.

2) Establishing the Central Da'wah Activities and Community Empowerment through the "Nurul Huda Pelangi Assembly" at the Provincial Level,

3) Ustadz / Ustadzah Leadership Training (LKU), Da'wah Cadre Training (LKD) or Da'wah Management Skills Training (LKMD) that is systematic and planned,

4) Increasing the efficiency and effectiveness of $d a^{\prime}$ wah through the development of new paradigms, the determination of appropriate media and targets, and the development of methods and tools / facilities,

5) Development of a network of cooperation with government agencies, entrepreneurs and mass media practitioners in order to increase the quality and quantity of propaganda,

6) Development and intensification of the missionary movement and spiritual guidance in vulnerable locations / places such as penitentiaries, hospitals, transmigration areas, isolated areas and so on,

7) Performing remembrance and repentance from every village / village and district in Riau Province.

In implementing a communication strategy, a communication plan must include goals, objectives and steps. Likewise, the communication planning of the BKMT Riau management 
in the development of Islamic Da'wah in the development of Islamic Da'wah in the form of program activities, whether in it includes the objectives, targets and steps. This can be traced among others from interviews with Mrs. Daharmi Astuti, Chairperson of the Da'wah Division and Issuance of BKMT Regional Administrators of Riau Province when explaining the program "Revitalizing the function of the mosque as a center for Taklim Assembly activities in the implementation of Da'wah and Amar Ma'ruf Nahi Munkar," as stated in BKMT documentation

Communication management in the development of Islamic Da'wah Management of the BKMT Riau management, among others, can be traced from the documentation of program activities in the Organization and Institutional Development of BKMT Region Management of Riau Province in the 2012-2017 period.

In an interview with Mrs. Sukma Erni, one of the BKMT administrators of the Riau Province Region said that to be able to achieve all the plans that have been programmed both for improving personal quality and the congregation of mothers under BKMT coaching will be more optimal if done in an organized manner. Organizations in this regard are very urgent in helping to process the application and existence of a Muslim. BKMT is one of the Da'wah organizations that regularly conducts $\mathrm{Da}$ 'wah with models of education, training, broadcasting, publication, empowerment of the ummah and other activities, more interesting is that BKMT is a women's da'wah organization that includes all levels of society both middle and upper middle and lower middle classes. ${ }^{1}$

According to Mrs. Septina Primawati Rusli, Chairman of the BKMT Riau management Regional Board, revealed that the BKMT Riau management in order to carry out the planned program, the board gave a division of work to each field to carry out its activities in accordance with the work plan. With the division of labor, each division will schedule the work plan so that there will be no overlap with the work of other fields, and efforts will be made to coordinate with each other in the implementation of the work program. Communication with fellow fields in the management will be able to support the work plan and can avoid various problems in the field. The next communication management is to always coordinate with all regional management in the Regency of the city in Riau Province. Coordination is carried out in order to motivate all BKMT members to always be active and remain enthusiastic in every planned activity. In addition to motivating coordination is also carried out in order to receive aspirations from BKMT members. When there are new things or obstacles that occur in the field and immediately require resolution.

The implementation of the communication strategy of the BKMT Riau Regional Management in the development of Islamic $D a^{\prime} w a h$, the next stage can be explained in the following description:

- Informative Communication

Informative communication is a method and technique for delivering messages as part of the application of the BKMT Riau Regional Management communication strategy in the development of Islamic Da'wah can be seen in the implementation of program activities as the following table:

\footnotetext{
${ }^{1}$ Sukma Erni, The member of the BKMT Riau Regional Management, Interview, Pekanbaru 7 January 2018.
} 
Table 1. The Use of Informative Communication Methods / Techniques PW. BKMT of Riau Province in the Development of Islamic Da'wah ${ }^{2}$

\begin{tabular}{|c|c|c|c|c|}
\hline No. & Activities & Implementation & Time/Place & Methods/Techniques \\
\hline 1. & $\begin{array}{l}\text { Welcoming the } \\
\text { Islamic New Year / } \\
\text { New Year Hijriyyah } \\
\text { (Tabligh Akbar) }\end{array}$ & $\begin{array}{l}\text { PW. BKMT } \\
\text { Riau Province }\end{array}$ & $\begin{array}{l}\text { 2012-2017, at the } \\
\text { An-Nur Grand } \\
\text { Mosque Pekanbaru }\end{array}$ & $\begin{array}{l}\text { Informative } \\
\text { Communication } \\
\text { (Announcement, } \\
\text { Invitations, } \\
\text { Speeches and } \\
\text { Lectures) }\end{array}$ \\
\hline 2. & $\begin{array}{l}\text { Commemoration of } \\
\text { the Prophet's } \\
\text { Birthday, (Tabligh } \\
\text { Akbar) }\end{array}$ & $\begin{array}{l}\text { PW. BKMT } \\
\text { Riau Province }\end{array}$ & $\begin{array}{l}\text { 2012-2017, at the } \\
\text { An-Nur Grand } \\
\text { Mosque Pekanbaru }\end{array}$ & $\begin{array}{l}\text { Informative } \\
\text { Communication } \\
\text { (Announcement, } \\
\text { Invitations, } \\
\text { Speeches and } \\
\text { Lectures) }\end{array}$ \\
\hline 3. & $\begin{array}{l}\text { Commemoration of } \\
\text { Isra' Mi'raj (Tabligh } \\
\text { Akbar) }\end{array}$ & $\begin{array}{l}\text { PW. BKMT } \\
\text { Riau Province }\end{array}$ & $\begin{array}{l}\text { 2012-2017, at the } \\
\text { An-Nur Grand } \\
\text { Mosque Pekanbaru }\end{array}$ & $\begin{array}{l}\text { Informative } \\
\text { Communication } \\
\text { (Announcement, } \\
\text { Invitation, Speech, } \\
\text { Lecture) }\end{array}$ \\
\hline 4. & $\begin{array}{l}\text { Love Ramadhan / } \\
\text { Safari Ramadhan } \\
\text { (Tausiah Ramadhan) }\end{array}$ & $\begin{array}{l}\text { PW. BKMT } \\
\text { Riau Province } \\
\text { Collaborates } \\
\text { with BK3S Riau } \\
\text { Province }\end{array}$ & $\begin{array}{l}\text { During Ramadhan } \\
\text { in } 2012-2017 \text {, in } \\
\text { mosques in } 12 \text { sub- } \\
\text { districts, } \\
\text { Pekanbaru City }\end{array}$ & $\begin{array}{l}\text { Informative } \\
\text { Communication } \\
\text { (Announcement, } \\
\text { Invitations, } \\
\text { Speeches and } \\
\text { Lectures) }\end{array}$ \\
\hline 5. & $\begin{array}{l}\text { Halal Bi Halal } \\
\text { Program and } \\
\text { Releasing Hajj } \\
\text { Pilgrims / (Tabligh } \\
\text { Akbar and Hajj } \\
\text { Tausiah) }\end{array}$ & $\begin{array}{l}\text { PW. BKMT } \\
\text { Riau Province }\end{array}$ & $\begin{array}{l}\text { Every end of } \\
\text { Shawwal during } \\
\text { 2012-2017, at the } \\
\text { An-Nur Grand } \\
\text { Mosque Pekanbaru }\end{array}$ & $\begin{array}{l}\text { Informative } \\
\text { Communication } \\
\text { (Announcement, } \\
\text { Invitations, } \\
\text { Speeches and } \\
\text { Lectures) }\end{array}$ \\
\hline 6. & $\begin{array}{l}\text { Love of the Al-Quran } \\
\text { /Recitation of } \\
\text { translation of the Al- } \\
\text { Quran }\end{array}$ & $\begin{array}{l}\text { PW. BKMT } \\
\text { Riau Province } \\
\text { Collaborates } \\
\text { with IKMI } \\
\text { Pekanbaru City }\end{array}$ & $\begin{array}{l}40 \text { Hour System } \\
\text { for } 2012-2017 \text {, at } \\
\text { the House of Mrs. } \\
\text { Hj. Hanum } \\
\text { Pekanbaru }\end{array}$ & $\begin{array}{l}\text { Informative } \\
\text { Communication } \\
\text { (Announcement, } \\
\text { Notification of } \\
\text { Schedule, and } \\
\text { Lecture) }\end{array}$ \\
\hline
\end{tabular}

Informational communication methods and techniques (informative communication) are recognized by the BKMT Riau Regional Management as the most effective and most widely used method in delivering messages in the development of Islamic Da'wah.

\footnotetext{
${ }^{2}$ Data Source, Data Processed From Documentation, BKMT of Riau Province, 2017.
} 
- Persuasive Communication

The use of persuasive communication methods / techniques as part of the implementation of the communication strategy of the BKMT Riau Regional Management in the development of Islamic $D a^{\prime}$ wah can be seen in the implementation of the program activities as the following table.

Table 2. The Use of Persuasive Communication Methods / Techniques PW. BKMT of Riau Province in the Development of Islamic Da'wah

\begin{tabular}{|l|l|l|l|l|}
\hline No. & Activities & Implementation & Time/Place & Methods/Techniques \\
\hline 1. & $\begin{array}{l}\text { Da'wah bil hal } \\
\text { (providing } \\
\text { compensation for } \\
\text { orphans in an } \\
\text { orphanage, } \\
\text { distributing nutritious } \\
\text { food aid, cooking } \\
\text { skills training, etc.) }\end{array}$ & $\begin{array}{l}\text { PW. BKMT } \\
\text { Riau Province }\end{array}$ & $\begin{array}{l}\text { Every 6 months, } \\
\text { during 2012- } \\
\text { 2017, }\end{array}$ & $\begin{array}{l}\text { Persuasive } \\
\text { Communication }\end{array}$ \\
\hline 2. & $\begin{array}{l}\text { Da'wah bil hal } \\
\text { (distributing zakat } \\
\text { mal and venture } \\
\text { capital assistance to } \\
\text { the poor, widows and } \\
\text { orphans) }\end{array}$ & $\begin{array}{l}\text { PW. BKMT } \\
\text { Riau Province }\end{array}$ & $\begin{array}{l}\text { Every year 4 } \\
\text { people, during } \\
\text { 2012-2017, }\end{array}$ & $\begin{array}{l}\text { (Provide Motivation, } \\
\text { Show Empathy, } \\
\text { Social Attention and } \\
\text { Concern) }\end{array}$ \\
\hline 3. & $\begin{array}{l}\text { Da'wah and } \\
\text { Community } \\
\text { Empowerment } \\
\text { (fostered village, } \\
\text { fostering home } \\
\text { industry skills for } \\
\text { poor widows and } \\
\text { school dropouts, } \\
\text { sewing and } \\
\text { embroidery skills, } \\
\text { handing over sewing } \\
\text { machines and } \\
\text { embroidery machines }\end{array}$ & $\begin{array}{l}\text { PW. BKMT } \\
\text { Riau Province }\end{array}$ & $\begin{array}{l}\text { During 2012- } \\
\text { 2017 }\end{array}$ & $\begin{array}{l}\text { Persuasive } \\
\text { Communication }\end{array}$ \\
\hline
\end{tabular}

Persuasive communication methods and techniques are the delivery or delivery of messages that aim to change or influence a person's beliefs, attitudes, and behaviors without any element of coercion so that the recipient of the message or target acts according to what is expected by the communicator is one of the methods and techniques applied by the BKMT Riau Regional Management in delivering messages in the development of Islamic Da'wah

- Curcive Commonication/ Instructive Ccommunication

Usually the methods and techniques of cursive communication or instructive communication used by the media are associative, namely by superimposing the presentation of messages on objects or events that are attracting the attention of the public. The use of 
cursive or instructive communication methods / techniques as part of the application the BKMT Riau Regional Management communication strategy in the development of Islamic Da'wah can be seen in the implementation of program activities as the following table.

Table 3. The Use of PW. Instructive Communication Methods / Techniques BKMT Riau Province under Development Islamic $D a^{\prime} w a h^{3}$

\begin{tabular}{|l|l|l|l|l|}
\hline No. & Activities & Implementation & Time/Place & Methods/Techniques \\
\hline 1. & $\begin{array}{l}\text { Welcoming the Islamic } \\
\text { New Year / Hijriyyah } \\
\text { New Year / Tabligh } \\
\text { Akbar } \text { with Ustadz } \\
\text { Abdul Shomad }\end{array}$ & $\begin{array}{l}\text { PW. BKMT } \\
\text { Riau Province }\end{array}$ & $\begin{array}{l}\text { 2012-2017, at the } \\
\text { An-Nur Grand } \\
\text { Mosque } \\
\text { Pekanbaru }\end{array}$ & $\begin{array}{l}\text { Instructive } \\
\text { Communication }\end{array}$ \\
\hline 2. & $\begin{array}{l}\text { Commemoration of the } \\
\text { Prophet's Birthday, / } \\
\text { Tabligh Akbar with } \\
\text { Prof. DR. Akhmad } \\
\text { Mujahidin, M.Ag }\end{array}$ & $\begin{array}{l}\text { PW. BKMT } \\
\text { Riau Province }\end{array}$ & $\begin{array}{l}\text { 2012-2017, at the } \\
\text { An-Nur Grand } \\
\text { Mosque } \\
\text { Pekanbaru }\end{array}$ & $\begin{array}{l}\text { (Islamic New Year } \\
\text { Moments) }\end{array}$ \\
\hline 3. & $\begin{array}{l}\text { Commemoration of } \\
\text { Isra 'Mi'raj / Tabligh } \\
\text { Akbar } \text { with Ustadz } \\
\text { Fakhri }\end{array}$ & $\begin{array}{l}\text { PW. BKMT } \\
\text { Riau Province }\end{array}$ & $\begin{array}{l}\text { 2012-2017, at the } \\
\text { An-Nur Grand } \\
\text { Mosque } \\
\text { Pekanbaru }\end{array}$ & $\begin{array}{l}\text { Instructive } \\
\text { Communication }\end{array}$ \\
\hline 5. & $\begin{array}{l}\text { Halal Bi Halal } \\
\text { Program and Releasing } \\
\text { Hajj / Tabligh Akbar } \\
\text { with Ustadz Abdul } \\
\text { Shomad }\end{array}$ & RW. BKMT & $\begin{array}{l}\text { At the end of } \\
\text { 2012-2017 } \\
\text { Rhawwal, Masjid }\end{array}$ & $\begin{array}{l}\text { (Moment of } \\
\text { Prophet's Birthday) }\end{array}$ \\
\hline
\end{tabular}

The methods and techniques of cursive communication or instructive communication as methods and techniques for delivering messages that are used by the media are of an association nature by superimposing the presentation of messages on objects or events that are attracting the attention of the public. Message in the development of Islamic $D a^{\prime} w a h$.

- Educative Communication

Educative communication methods and techniques are a form of educating messages, namely giving an idea to the audience based on facts, opinions and experiences that can be justified intentionally, regularly and planned with the aim of influencing and changing behavior as desired. The use of this educative method will have a profound effect on the audience even though this will take a little longer than using the persuasive method. ${ }^{4}$ The use of educative communication in the delivery of messages as part of the implementation of the communication strategy of the BKMT Riau Regional Management in the development of Islamic Da'wah can be seen in the implementation of the program activities as the following table.

\footnotetext{
${ }^{3}$ Data Sources, Data Processed From BKMT Documentation of Riau Province, 2017.

${ }^{4}$ Marhaeni Fajar, Ilmu Komunikasi Teori dan Praktik, (Yogyakarta: Graha Ilmu, 2009), pp. 202-203.
} 
Table 4. The Use of Educational Communication Methods in the Development of Islamic $D a^{\prime}$ wah of PW. BKMT Riau Province ${ }^{5}$

\begin{tabular}{|c|c|c|c|c|}
\hline No & Activities & Implementation & Time/Place & Methods/Techniques \\
\hline 1. & $\begin{array}{l}\text { Community Service, } \\
\text { Guidance and } \\
\text { Counseling "Anti- } \\
\text { Drugs, Anti } \\
\text { Radicalism and } \\
\text { Terrorism" }\end{array}$ & $\begin{array}{l}\text { PW. BKMT Riau } \\
\text { Province } \\
\text { Collaborates with } \\
\text { Riau Regional } \\
\text { Police }\end{array}$ & $\begin{array}{l}\text { Scheduled at } \\
\text { "Balai Nurul } \\
\text { Huda Pelangi" } \\
\text { Pekanbaru }\end{array}$ & $\begin{array}{l}\text { Educative } \\
\text { Communication / } \\
\text { Lecture, Discussion } \\
\text { and Question and } \\
\text { Answer }\end{array}$ \\
\hline 2. & $\begin{array}{l}\text { Guidance for } \\
\text { Women and } \\
\text { Children Prisoners, } \\
\text { Lectures and } \\
\text { Tutorials }\end{array}$ & $\begin{array}{l}\text { PW. BKMT Riau } \\
\text { Province } \\
\text { Cooperates with } \\
\text { Dep. Kumdang and } \\
\text { IKMI Pekanbaru } \\
\text { City }\end{array}$ & $\begin{array}{l}\text { Every Ramadhan } \\
\text { Month in 2012- } \\
\text { 2017, in the } \\
\text { Lapas of Women } \\
\text { and Children in } \\
\text { Class 2B } \\
\text { Pekanbaru }\end{array}$ & $\begin{array}{l}\text { Educative } \\
\text { Communication / } \\
\text { Lecture, Discussion } \\
\text { and Question and } \\
\text { Answer }\end{array}$ \\
\hline 3. & $\begin{array}{l}\text { Community } \\
\text { Guidance and } \\
\text { Counseling in } \\
\text { Nursing Homes / } \\
\text { Practical Worship } \\
\text { Guidance }\end{array}$ & $\begin{array}{l}\text { PW. BKMT Riau } \\
\text { Province } \\
\text { Cooperates with } \\
\text { Ministry of Social } \\
\text { Affairs, Pekanbaru } \\
\text { City }\end{array}$ & $\begin{array}{l}\text { Every } 3 \text { Months } \\
\text { during 2012- } \\
\text { 2017, at } \\
\text { Pekanbaru } \\
\text { Nursing Homes }\end{array}$ & $\begin{array}{l}\text { Educative } \\
\text { Communication / } \\
\text { Lecture, Discussion, } \\
\text { Question and } \\
\text { Answer and Practice }\end{array}$ \\
\hline 4. & $\begin{array}{l}\text { Health and Nutrition } \\
\text { Services, Guidance } \\
\text { and Counseling }\end{array}$ & $\begin{array}{l}\text { PW. BKMT Riau } \\
\text { Province } \\
\text { Collaborates with } \\
\text { Pekanbaru City } \\
\text { Health Office }\end{array}$ & $\begin{array}{l}\text { Scheduled at } \\
\text { "Balai Nurul } \\
\text { Huda Pelangi" } \\
\text { Pekanbaru }\end{array}$ & $\begin{array}{l}\text { Educative } \\
\text { Communication / } \\
\text { Lecture, Discussion } \\
\text { and Question and } \\
\text { Answer }\end{array}$ \\
\hline 5. & $\begin{array}{l}\text { Prospective Bride } \\
\text { and Grooming } \\
\text { Course Sakinah } \\
\text { Family }\end{array}$ & $\begin{array}{l}\text { PW. BKMT Riau } \\
\text { Province } \\
\text { Collaborates with } \\
\text { Ministry of } \\
\text { Religion Pekanbaru } \\
\text { City }\end{array}$ & $\begin{array}{l}\text { Scheduled at } \\
\text { "Balai Suscatin" } \\
\text { Pekanbaru City }\end{array}$ & $\begin{array}{l}\text { Educative } \\
\text { Communication / } \\
\text { Lecture, Discussion } \\
\text { and Question and } \\
\text { Answer }\end{array}$ \\
\hline 6. & $\begin{array}{l}\text { Home Industry } \\
\text { Education and } \\
\text { Training }\end{array}$ & $\begin{array}{l}\text { PW. BKMT Riau } \\
\text { Province } \\
\text { Cooperates with } \\
\text { Deperindag } \\
\text { Pekanbaru City }\end{array}$ & $\begin{array}{l}\text { Scheduled at } \\
\text { "Balai Nurul } \\
\text { Huda Pelangi" } \\
\text { Pekanbaru }\end{array}$ & $\begin{array}{l}\text { Educative } \\
\text { Communication / } \\
\text { Lecture, Discussion } \\
\text { and Question and } \\
\text { Answer }\end{array}$ \\
\hline
\end{tabular}

- Redundancy / Repetition Methods / Techniques

Methods and techniques of Communication, is a way of influencing audiences by repeating messages. This method allows the opportunity to get greater public attention,

${ }^{5}$ Data Sources, Data Processed From BKMT Documentation of Riau Province, 2017. 
important messages easily remembered by the audience and provide opportunities for communicators to correct mistakes made previously. With the use of this method, many benefits can be drawn from it. The benefits include that the public will pay more attention to the message conveyed by the communicator. This is because it is reversed by the message that is not repeated, so that it will attract a lot of attention. Nevertheless, the communicator should pay attention to variations that are interesting and not boring in repeating the message.

Table 5. The Use of Redundancy / Repetition Communication Methods / Techniques of PW.

BKMT Riau Province in the Development of Islamic Da'wah

\begin{tabular}{|l|l|l|l|l|}
\hline No. & Activities & Implementation & Time/Place & Methods/Techniques \\
\hline 1. & $\begin{array}{l}\text { Welcoming the } \\
\text { Islamic New Year / } \\
\text { Hijriyyah New Year / } \\
\text { Tabligh Akbar with } \\
\text { Ustadz Abdul } \\
\text { Shomad }\end{array}$ & $\begin{array}{l}\text { PW. BKMT } \\
\text { Riau Province }\end{array}$ & $\begin{array}{l}\text { 2012-2017, at the } \\
\text { An-Nur Grand } \\
\text { Mosque } \\
\text { Pekanbaru }\end{array}$ & $\begin{array}{l}\text { Repetition } \\
\text { Communication } \\
\text { (redundancy/ } \\
\text { repetition) }\end{array}$ \\
\hline 2. & $\begin{array}{l}\text { Commemoration of } \\
\text { the Prophet's } \\
\text { Birthday, / Tabligh } \\
\text { Akbar } \text { with Prof. DR. } \\
\text { Akhmad Mujahidin, } \\
\text { M.Ag }\end{array}$ & $\begin{array}{l}\text { PW. BKMT } \\
\text { Riau Province }\end{array}$ & $\begin{array}{l}\text { 2012-2017, at the } \\
\text { An-Nur Grand } \\
\text { Mosque } \\
\text { Pekanbaru }\end{array}$ & $\begin{array}{l}\text { Repetition } \\
\text { Communication } \\
\text { (redundancy/ } \\
\text { repetition) }\end{array}$ \\
\hline 3. & $\begin{array}{l}\text { Commemoration of } \\
\text { Isra 'Mi'raj / Tabligh } \\
\text { Akbar } \text { with Ustadz } \\
\text { Fakhri }\end{array}$ & $\begin{array}{l}\text { PW. BKMT } \\
\text { Riau Province }\end{array}$ & $\begin{array}{l}\text { 2012-2017, at the } \\
\text { An-Nur Grand } \\
\text { Mosque } \\
\text { Pekanbaru }\end{array}$ & $\begin{array}{l}\text { Repetition } \\
\text { Communication } \\
\text { (redundancy/ } \\
\text { repetition) }\end{array}$ \\
\hline 4. & $\begin{array}{l}\text { Halal Bi Halal } \\
\text { Program and } \\
\text { Releasing Hajj / } \\
\text { Tabligh Akbar with } \\
\text { Ustadz Abdul } \\
\text { Shomad }\end{array}$ & $\begin{array}{l}\text { PW. BKMT } \\
\text { Provinsi Riau }\end{array}$ & $\begin{array}{l}\text { At the end of } \\
\text { 2012-2017 } \\
\text { Shawwal, Masjid } \\
\text { Raya An-Nur } \\
\text { Pekanbaru }\end{array}$ & $\begin{array}{l}\text { Repetition } \\
\text { Communication } \\
\text { (redundancy/ } \\
\text { repetition) }\end{array}$ \\
\hline
\end{tabular}

Repetition communication methods and techniques as a way to influence audiences by repeating messages. This method allows the opportunity to get greater public attention, important messages easily remembered by the public and provides an opportunity for communicators to correct mistakes made previously. This is one of the methods and techniques applied by the BKMT Management of Riau Province in delivering messages in the development of Islamic Da'wah.

- Canalizing Methods / Techniques

The method and technique of deepening means that the communicator provides certain channels to master the motives that exist in the audience. In the process of canalizing also includes understanding and examining the influence of groups on individuals or audiences. In this method, the communication process is the communicator first knows the audience and 
starts giving ideas in accordance with the personality, attitudes and motives of the audience and then changed little by little toward the goals desired communicator.

Table 6. The Use of Canalizing Methods / Techniques PW. BKMT of Riau Province in the Development of Islamic $D a^{\prime} w a h^{6}$

\begin{tabular}{|l|l|l|l|l|}
\hline No. & Activities & Implementation & Time/Place & Methods/Techniques \\
\hline 1. & $\begin{array}{l}\text { Regular Study of } \\
\text { Aqeedah / } \\
\text { Monotheism }\end{array}$ & $\begin{array}{l}\text { PW. BKMT } \\
\text { Riau Province }\end{array}$ & $\begin{array}{l}\text { Year 2012-2017, } \\
\text { Week I, at the An- } \\
\text { Nur Pekanbaru } \\
\text { Mosque }\end{array}$ & $\begin{array}{l}\text { Deepening } \\
\text { Communication } \\
\text { (canalizing) }\end{array}$ \\
\hline 2. & $\begin{array}{l}\text { Routine Study of } \\
\text { Worship Fiqh } \\
\text { and Women's } \\
\text { Fiqh }\end{array}$ & $\begin{array}{l}\text { PW. BKMT } \\
\text { Riau Province }\end{array}$ & $\begin{array}{l}\text { 2012-2017, Week } \\
\text { II, at the An-Nur } \\
\text { Grand Mosque } \\
\text { Pekanbaru }\end{array}$ & $\begin{array}{l}\text { Deepening } \\
\text { Communication } \\
\text { (canalizing) }\end{array}$ \\
\hline 3. & $\begin{array}{l}\text { Regular recitation } \\
\text { of Muamalah } \\
\text { Fiqh } \text { Field }\end{array}$ & $\begin{array}{l}\text { PW. BKMT } \\
\text { Riau Province }\end{array}$ & $\begin{array}{l}\text { 2012-2017, Week } \\
\text { III, at the An-Nur } \\
\text { Pekanbaru Mosque }\end{array}$ & $\begin{array}{l}\text { Deepening } \\
\text { Communication } \\
\text { (canalizing) }\end{array}$ \\
\hline 4. & $\begin{array}{l}\text { Routine study of } \\
\text { the field of } \\
\text { Sufism }\end{array}$ & $\begin{array}{l}\text { PW. BKMT } \\
\text { Riau Province }\end{array}$ & $\begin{array}{l}\text { 2012-2017, Week } \\
\text { IV, An-Nur } \\
\text { Pekanbaru Great } \\
\text { Mosque }\end{array}$ & $\begin{array}{l}\text { Deepening } \\
\text { Communication } \\
\text { (canalizing) }\end{array}$ \\
\hline
\end{tabular}

The method and deepening technique means that the communicator provides certain channels to master the motives that exist in the audience, including understanding and examining the influence of groups on individuals or audiences is one of the methods and techniques applied by the Regional Management BKMT Riau Province in delivering messages in the development of Islamic Da'wah

The application of communication characteristics of the BKMT Regional Board of Riau Province in the development of Islamic Da'wah in the next stage can be traced from the model of Da'wah communication that is used, in detail can be explained in the description which includes: communicator / sender of the message, the message conveyed, the communicant / receiver of the message and the media used in delivering messages.

a. Communicator

Communicators in this discussion are people, groups or institutions that take the initiative to deliver a message to the communicant, or recipient of the message. ${ }^{7}$ Based on this, the communicators referred to in general are the whole Regional Board of Management of the Taklim Assembly Contact Board (BKMT) of Riau Province, specifically the Management Offices of Da'wah and Publishing and those who play a role in the development of $D a^{\prime} w a h$ in the Riau Province. Based on the documentation data, it is known that the BKMT Regional Administrators of Riau Province in Da'wah Division can be stated as follows.

\footnotetext{
${ }^{6}$ Data Sources, Data Processed From BKMT Documentation of Riau Province, 2017.

${ }^{7}$ Y.S. Gunadi, Himpunan Istilah Komunikasi, (Jakarta : PT. Grasindo, 2008), p. 70.
} 
Table 7. The Communicators in the Development of Islamic Da'wah in the Da'wah Division of PW. BKMT Riau Province ${ }^{8}$

\begin{tabular}{|l|l|l|}
\hline No. & Name & Implementation of Tasks / Activities \\
\hline 1. & Dra. Hj. Maliha Azis & MMQ \\
2. & Dr. Daharmi Astuti, Lc, M.Ag & Young Da'i Selection and Training \\
3. & Hafifah Rasyid & Dialog RTV \\
4. & Badriyah. Msi & Da'wah in Orphanages \& Nursing Homes \\
5. & Hj. Nurmala, S.Ag & Same as above. \\
6. & Dr. Hj. Siti Rahmah, M.Si & Da'wah at LAPAS woman \& child, Suscatin \\
7. & Dr. Hj Nurhasanah, M.Ag & Same as above. \\
8. & Dr. Hj. Alfiah, M.Ag & Same as above. \\
9. & Dr. Sukma Erni & Same as above \\
\hline
\end{tabular}

Table 8. The Communicators in the Development of Islamic Da'wah of PW. BKMT Riau Province $^{9}$

\begin{tabular}{|l|l|l|l|l|}
\hline No. & \multicolumn{1}{|c|}{ Activities } & Implementation & Opening Speech & Muballigh/ Tutor \\
\hline 1. & $\begin{array}{l}\text { Welcoming the } \\
\text { Islamic New Year / } \\
\text { Hijriyyah New Year / } \\
\text { Tabligh Akbar }\end{array}$ & $\begin{array}{l}\text { PW. BKMT } \\
\text { Riau Province }\end{array}$ & $\begin{array}{l}\text { Chair of PW. } \\
\text { BKMT Riau } \\
\text { Province }\end{array}$ & $\begin{array}{l}\text { Ustadz H. Abdul } \\
\text { Shomad, Lc., } \\
\text { Village }\end{array}$ \\
\hline 2. & $\begin{array}{l}\text { Commemoration of } \\
\text { the Prophet's } \\
\text { Birthday, / Tabligh } \\
\text { Akbar }\end{array}$ & $\begin{array}{l}\text { PW. BKMT } \\
\text { Riau Province }\end{array}$ & $\begin{array}{l}\text { Chair of PW. } \\
\text { BKMT Riau } \\
\text { Province }\end{array}$ & $\begin{array}{l}\text { Prof. DR. } \\
\text { Akhmad } \\
\text { Mujahidin, M.Ag }\end{array}$ \\
\hline 3. & $\begin{array}{l}\text { Commemoration of } \\
\text { Isra 'Mi'raj / Tabligh } \\
\text { Akbar }\end{array}$ & $\begin{array}{l}\text { PW. BKMT } \\
\text { Riau Province }\end{array}$ & $\begin{array}{l}\text { Chair of PW. } \\
\text { BKMT Riau } \\
\text { Province }\end{array}$ & $\begin{array}{l}\text { Ustadz Fakhri, } \\
\text { Lc., MA }\end{array}$ \\
\hline 4. & $\begin{array}{l}\text { Halal Bi Halal } \\
\text { Program and } \\
\text { Releasing Hajj / } \\
\text { Tabligh Akbar }\end{array}$ & $\begin{array}{l}\text { PW. BKMT } \\
\text { Riau Province } \\
\text { Chair of PW. } \\
\text { BKMT Riau } \\
\text { Province }\end{array}$ & $\begin{array}{l}\text { Ustadz H. Abdul } \\
\text { Shomad, Lc., } \\
\text { Village }\end{array}$ \\
\hline 5. & $\begin{array}{l}\text { Community Guidance } \\
\text { and Counseling "Anti- } \\
\text { Drugs, Anti } \\
\text { Radicalism and } \\
\text { Terrorism" }\end{array}$ & $\begin{array}{l}\text { PW. BKMT } \\
\text { Riau Province } \\
\text { Collaborates } \\
\text { with Riau } \\
\text { Regional Police, } \\
\text { BNN and BNPT }\end{array}$ & $\begin{array}{l}\text { Chair of PW. } \\
\text { BKMT Riau } \\
\text { Province and the } \\
\text { Head of the Riau } \\
\text { Regional Police } \\
\text { Bimas }\end{array}$ & $\begin{array}{l}\text { BNN and BNPT } \\
\text { Riau Police }\end{array}$ \\
\hline 6. & $\begin{array}{l}\text { Guidance for Women } \\
\text { and Children } \\
\text { Prisoners, Lectures } \\
\text { and Tutorials }\end{array}$ & $\begin{array}{l}\text { PW. BKMT } \\
\text { Riau Province } \\
\text { Cooperates with } \\
\text { Dep. Kumdang }\end{array}$ & $\begin{array}{l}\text { BKMT Riau } \\
\text { Province }\end{array}$ & $\begin{array}{l}\text { Dep. Kumdang } \\
\text { and IKMI } \\
\text { Pekanbaru City }\end{array}$ \\
\hline
\end{tabular}

\footnotetext{
${ }^{8}$ Data Sources, Documentation, Details on the Tasks of the Regional Managers of Taklim Assembly Contact Board (BKMT) of Riau Province, Period 2012-2017, Pekanbaru, 2017.

${ }^{9}$ Data Sources, Data Processed From BKMT Documentation of Riau Province, 2017.
} 


\begin{tabular}{|c|c|c|c|c|}
\hline & & $\begin{array}{l}\text { and IKMI } \\
\text { Pekanbaru City }\end{array}$ & & \\
\hline 7. & $\begin{array}{l}\text { Community Service, } \\
\text { Guidance and } \\
\text { Counseling in } \\
\text { Nursing Homes / } \\
\text { Practical Worship } \\
\text { Guidance }\end{array}$ & $\begin{array}{l}\text { PW. BKMT } \\
\text { Riau Province } \\
\text { Collaborates } \\
\text { with Pekanbaru } \\
\text { Ministry of } \\
\text { Social Affairs } \\
\text { and Pekanbaru } \\
\text { City IKMI }\end{array}$ & $\begin{array}{l}\text { Chair of PW. } \\
\text { BKMT Riau } \\
\text { Province }\end{array}$ & $\begin{array}{l}\text { Pekanbaru Social } \\
\text { Ministry and } \\
\text { IKMI Pekanbaru } \\
\text { City }\end{array}$ \\
\hline 8. & $\begin{array}{l}\text { Health and Nutrition } \\
\text { Services, Guidance } \\
\text { and Counseling }\end{array}$ & $\begin{array}{l}\text { PW. BKMT } \\
\text { Riau Province } \\
\text { Collaborates } \\
\text { with Pekanbaru } \\
\text { City Health } \\
\text { Office } \\
\end{array}$ & $\begin{array}{l}\text { Chair of PW. } \\
\text { BKMT Riau } \\
\text { Province }\end{array}$ & $\begin{array}{l}\text { Pekanbaru City } \\
\text { Health Office }\end{array}$ \\
\hline 9. & $\begin{array}{l}\text { Prospective Bride and } \\
\text { Grooming Course } \\
\text { Sakinah Family }\end{array}$ & $\begin{array}{l}\text { PW. BKMT } \\
\text { Riau Province } \\
\text { Collaborates } \\
\text { with Ministry of } \\
\text { Religion } \\
\text { Pekanbaru City }\end{array}$ & $\begin{array}{l}\text { Chair of PW. } \\
\text { BKMT Riau } \\
\text { Province }\end{array}$ & $\begin{array}{l}\text { Ministry of } \\
\text { Religion } \\
\text { Pekanbaru City }\end{array}$ \\
\hline 10. & $\begin{array}{l}\text { Home Industry } \\
\text { Education and } \\
\text { Training }\end{array}$ & $\begin{array}{l}\text { PW. BKMT } \\
\text { Riau Province } \\
\text { Cooperates with } \\
\text { Deperindag } \\
\text { Pekanbaru City }\end{array}$ & $\begin{array}{l}\text { Chair of PW. } \\
\text { BKMT Riau } \\
\text { Province }\end{array}$ & $\begin{array}{l}\text { Deperindag } \\
\text { Pekanbaru City }\end{array}$ \\
\hline
\end{tabular}

Because the effectiveness of the message is greatly influenced by who is the communicator, in the effort to develop Islamic Da'wah, BKMT Regional Management of Riau Province are required to be selective and clever in choosing and choosing which communicators are most responsible and can cause attention, encouragement and motivation to the congregation in participating in various activities.

b. Message

The communication messages delivered by the Regional Board of BKMT Riau Province in the development of Islamic $D a^{\prime}$ wah can be seen in the table as follows. 
Table 9. The Communicators in the Development of Islamic Da'wah of PW. BKMT Riau Province $^{10}$

\begin{tabular}{|c|c|c|c|c|}
\hline No. & Activities & Implementation & Muballigh/ Tutor & Messages \\
\hline 1. & $\begin{array}{l}\text { Welcoming the } \\
\text { Islamic New Year / } \\
\text { Hijriyyah New } \\
\text { Year / Tabligh } \\
\text { Akbar }\end{array}$ & $\begin{array}{l}\text { PW. BKMT Riau } \\
\text { Province }\end{array}$ & $\begin{array}{l}\text { Ustadz H. Abdul } \\
\text { Shomad, Lc., } \\
\text { Village }\end{array}$ & $\begin{array}{l}\text { Repentance, } \\
\text { Hoping for } \\
\text { Allah's Grace } \\
\text { and Grace, } \\
\text { Taqarrub }\end{array}$ \\
\hline 2. & $\begin{array}{l}\text { Commemoration of } \\
\text { the Prophet's } \\
\text { Birthday, / Tabligh } \\
\text { Akbar }\end{array}$ & $\begin{array}{l}\text { PW. BKMT Riau } \\
\text { Province }\end{array}$ & $\begin{array}{l}\text { Prof. Dr. Akhmad } \\
\text { Mujahidin, M.Ag }\end{array}$ & Same as above \\
\hline 3. & $\begin{array}{l}\text { Commemoration of } \\
\text { Isra 'Mi'raj / } \\
\text { Tabligh Akbar }\end{array}$ & $\begin{array}{l}\text { PW. BKMT Riau } \\
\text { Province }\end{array}$ & $\begin{array}{l}\text { Ustadz Fakhri, Lc., } \\
\text { MA }\end{array}$ & Same as above \\
\hline 4. & $\begin{array}{l}\text { Halal Bi Halal } \\
\text { Program and } \\
\text { Releasing Hajj / } \\
\text { Tabligh Akbar }\end{array}$ & $\begin{array}{l}\text { PW. BKMT Riau } \\
\text { Province }\end{array}$ & $\begin{array}{l}\text { Ustadz H. Abdul } \\
\text { Shomad, Lc., } \\
\text { Village }\end{array}$ & Same as above \\
\hline 5. & $\begin{array}{l}\text { Community } \\
\text { Guidance and } \\
\text { Counseling "Anti- } \\
\text { Drugs, Anti } \\
\text { Radicalism and } \\
\text { Terrorism" }\end{array}$ & $\begin{array}{l}\text { PW. BKMT Riau } \\
\text { Province } \\
\text { Collaborates with } \\
\text { Riau Regional } \\
\text { Police, BNN and } \\
\text { BNPT }\end{array}$ & $\begin{array}{l}\text { BNN and BNPT } \\
\text { Riau Police }\end{array}$ & $\begin{array}{l}\text { Become a } \\
\text { Muslim, } \\
\text { Rahmatan Lil } \\
\text { Alamin }\end{array}$ \\
\hline 6. & $\begin{array}{l}\text { Guidance for } \\
\text { Women and } \\
\text { Children Prisoners, } \\
\text { Lectures and } \\
\text { Tutorials }\end{array}$ & $\begin{array}{l}\text { PW. BKMT Riau } \\
\text { Province } \\
\text { Cooperates with } \\
\text { Dep. Kumdang } \\
\text { and IKMI } \\
\text { Pekanbaru City }\end{array}$ & $\begin{array}{l}\text { Dep. Kumdang and } \\
\text { IKMI Pekanbaru } \\
\text { City }\end{array}$ & $\begin{array}{l}\text { Become a } \\
\text { Muslim / } \\
\text { Muslimah } \\
\text { Kaffah and } \\
\text { Benefit Others }\end{array}$ \\
\hline 7. & $\begin{array}{l}\text { Community } \\
\text { Service, Guidance } \\
\text { and Counseling in } \\
\text { Nursing Homes / } \\
\text { Practical Worship } \\
\text { Guidance }\end{array}$ & $\begin{array}{l}\text { PW. BKMT Riau } \\
\text { Province } \\
\text { Collaborates with } \\
\text { Ministry of Social } \\
\text { Affairs and IKMI } \\
\text { Pekanbaru City }\end{array}$ & $\begin{array}{l}\text { Pekanbaru Social } \\
\text { Ministry and IKMI } \\
\text { Pekanbaru City }\end{array}$ & $\begin{array}{l}\text { Repentance, } \\
\text { Hoping for } \\
\text { Allah's Grace } \\
\text { and Grace, } \\
\text { Taqarrub }\end{array}$ \\
\hline 8. & $\begin{array}{l}\text { Health and } \\
\text { Nutrition Services, } \\
\text { Guidance and } \\
\text { Counseling }\end{array}$ & $\begin{array}{l}\text { PW. BKMT Riau } \\
\text { Province } \\
\text { Collaborates with } \\
\text { Pekanbaru City } \\
\text { Health Office }\end{array}$ & $\begin{array}{l}\text { Pekanbaru City } \\
\text { Health Office }\end{array}$ & $\begin{array}{l}\text { Halal and } \\
\text { Good Food to } \\
\text { Strengthen } \\
\text { Worship }\end{array}$ \\
\hline
\end{tabular}

${ }^{10}$ Data Sources, Data Processed From BKMT Documentation of Riau Province, 2017. 


\begin{tabular}{|l|l|l|l|l|}
\hline 9. & $\begin{array}{l}\text { Prospective Bride } \\
\text { and Grooming } \\
\text { Course Sakinah } \\
\text { Family }\end{array}$ & $\begin{array}{l}\text { PW. BKMT Riau } \\
\text { Province } \\
\text { Collaborates with } \\
\text { Ministry of } \\
\text { Religion } \\
\text { Pekanbaru City }\end{array}$ & $\begin{array}{l}\text { Ministry of } \\
\text { Religion Pekanbaru } \\
\text { City }\end{array}$ & $\begin{array}{l}\text { A Muslim } \\
\text { Family That } \\
\text { Sakinah. } \\
\text { Mawaddah } \\
\text { and Rahmah }\end{array}$ \\
\hline 10. & $\begin{array}{l}\text { Home Industry } \\
\text { Education and } \\
\text { Training }\end{array}$ & Same as above & $\begin{array}{l}\text { Deperindag } \\
\text { Pekanbaru City }\end{array}$ & $\begin{array}{l}\text { Become a } \\
\text { Muslimah who } \\
\text { is creative and } \\
\text { useful for } \\
\text { others }\end{array}$ \\
\hline
\end{tabular}

So that the messages of Islamic $D a^{\prime}$ wah delivered contain a combination of thoughts and feelings, which can be ideas, information, complaints of beliefs, appeals, suggestions, etc. can run effectively and efficiently, the BKMT Regional Management of Riau Province needs to design and plan well and mature the various messages.

c. Communication / Communication Targets

Communicating or targeting communication activities in the development of Islamic Da'wah of BKMT Regional Management of Riau Province, can be seen in the table as follows:

Table 10. The Communication / Communication Objectives in the Development of Islamic Da'wah of PW. BKMT Riau Province ${ }^{11}$

\begin{tabular}{|c|c|c|c|c|}
\hline No. & Activities & Communicator I & Comunicator II & $\begin{array}{l}\text { Communicate / } \\
\text { Target }\end{array}$ \\
\hline 1. & $\begin{array}{l}\text { Welcoming the } \\
\text { Islamic New Year / } \\
\text { Hijriyyah New } \\
\text { Year / Tabligh } \\
\text { Akbar }\end{array}$ & $\begin{array}{l}\text { PW. BKMT Riau } \\
\text { Province }\end{array}$ & $\begin{array}{l}\text { Ustadz H. Abdul } \\
\text { Shomad, Lc., } \\
\text { Village }\end{array}$ & $\begin{array}{l}\text { PW. member. } \\
\text { BKMT Riau } \\
\text { Province, Jama'ah, } \\
\text { Invitations and } \\
\text { Participants }\end{array}$ \\
\hline 2. & $\begin{array}{l}\text { Commemoration of } \\
\text { the Prophet's } \\
\text { Birthday, / Tabligh } \\
\text { Akbar }\end{array}$ & $\begin{array}{l}\text { PW. BKMT Riau } \\
\text { Province }\end{array}$ & $\begin{array}{l}\text { Prof. Dr. Akhmad } \\
\text { Mujahidin, M.Ag }\end{array}$ & Same as above \\
\hline 3. & $\begin{array}{l}\text { Commemoration of } \\
\text { Isra 'Mi'raj / } \\
\text { Tabligh Akbar }\end{array}$ & $\begin{array}{l}\text { PW. BKMT Riau } \\
\text { Province }\end{array}$ & $\begin{array}{l}\text { Ustadz Fakhri, } \\
\text { Lc., MA }\end{array}$ & Same as above \\
\hline 4. & $\begin{array}{l}\text { Halal Bi Halal } \\
\text { Program and } \\
\text { Releasing Hajj / } \\
\text { Tabligh Akbar }\end{array}$ & $\begin{array}{l}\text { PW. BKMT Riau } \\
\text { Province }\end{array}$ & $\begin{array}{l}\text { Ustadz H. Abdul } \\
\text { Shomad, Lc., } \\
\text { Village }\end{array}$ & Same as above \\
\hline 5. & $\begin{array}{l}\text { Community } \\
\text { Guidance and } \\
\text { Counseling "Anti- }\end{array}$ & $\begin{array}{l}\text { PW. BKMT Riau } \\
\text { Province }\end{array}$ & $\begin{array}{l}\text { Resource persons } \\
\text { from BNN and }\end{array}$ & Same as above \\
\hline
\end{tabular}

\footnotetext{
${ }^{11}$ Data Sources, Data Processed From BKMT Documentation of Riau Province, 2017.
} 


\begin{tabular}{|c|c|c|c|c|}
\hline & $\begin{array}{l}\text { Drugs, Anti } \\
\text { Radicalism and } \\
\text { Terrorism" }\end{array}$ & & $\begin{array}{l}\text { BNPT Riau } \\
\text { Police }\end{array}$ & \\
\hline 6. & $\begin{array}{l}\text { Guidance for } \\
\text { Women and } \\
\text { Children Prisoners, } \\
\text { Lectures and } \\
\text { Tutorials }\end{array}$ & $\begin{array}{l}\text { PW. BKMT Riau } \\
\text { Province }\end{array}$ & $\begin{array}{l}\text { Resource Person } \\
\text { from the } \\
\text { Department of } \\
\text { Agriculture. } \\
\text { Kumdang and } \\
\text { IKMI Pekanbaru } \\
\text { City }\end{array}$ & $\begin{array}{l}\text { Female Prisoners } \\
\text { and Children } \\
\text { Prison Class } 2 \text { B } \\
\text { Pekanbaru }\end{array}$ \\
\hline 7. & $\begin{array}{l}\text { Community } \\
\text { Service, Guidance } \\
\text { and Counseling in } \\
\text { Nursing Homes / } \\
\text { Practical Worship } \\
\text { Guidance }\end{array}$ & $\begin{array}{l}\text { PW. BKMT Riau } \\
\text { Province }\end{array}$ & $\begin{array}{l}\text { Resource persons } \\
\text { from the Ministry } \\
\text { of Social Affairs } \\
\text { Pekanbaru and } \\
\text { IKMI Pekanbaru } \\
\text { City }\end{array}$ & $\begin{array}{l}\text { Communities in } \\
\text { Pekanbaru Nursing } \\
\text { Home }\end{array}$ \\
\hline 8. & $\begin{array}{l}\text { Health and } \\
\text { Nutrition Services, } \\
\text { Guidance and } \\
\text { Counseling }\end{array}$ & $\begin{array}{l}\text { PW. BKMT Riau } \\
\text { Province }\end{array}$ & $\begin{array}{l}\text { Resource Person } \\
\text { from Pekanbaru } \\
\text { City Health } \\
\text { Office }\end{array}$ & $\begin{array}{l}\text { Halal and Good } \\
\text { Food to Strengthen } \\
\text { Worship }\end{array}$ \\
\hline 9. & $\begin{array}{l}\text { Prospective Bride } \\
\text { and Grooming } \\
\text { Course Sakinah } \\
\text { Family }\end{array}$ & $\begin{array}{l}\text { PW. BKMT Riau } \\
\text { Province }\end{array}$ & $\begin{array}{l}\text { Speaker from } \\
\text { Pekanbaru City } \\
\text { Ministry of } \\
\text { Religion }\end{array}$ & $\begin{array}{l}\text { Future bride and } \\
\text { groom }\end{array}$ \\
\hline 10. & $\begin{array}{l}\text { Home Industry } \\
\text { Education and } \\
\text { Training }\end{array}$ & $\begin{array}{l}\text { PW. BKMT Riau } \\
\text { Province }\end{array}$ & $\begin{array}{l}\text { Resource Person } \\
\text { from the } \\
\text { Deperindag of } \\
\text { Pekanbaru City }\end{array}$ & $\begin{array}{l}\text { PW. member. } \\
\text { BKMT Riau } \\
\text { Province, Jama'ah, } \\
\text { Invitations and } \\
\text { Participants }\end{array}$ \\
\hline
\end{tabular}

The situation, conditions and matters of the congregation as the target recipient of the message greatly affect the effectiveness and efficiency in delivering the messages of Islamic Da'wah delivered by the Regional Management BKMT of Riau Province.

d. Media / Communication Aids

Media or communication aids in the development of Islamic Da'wah of the Regional Management BKMT of Riau Province

, can be seen in the table as follows. 
Table 11. The Media or Communication Aids in Development of Islamic Da'wah of PW. BKMT Riau Province ${ }^{12}$

\begin{tabular}{|c|c|c|c|c|}
\hline No. & Activities & Media I & Media II & Media III \\
\hline 1. & $\begin{array}{l}\text { Welcoming the } \\
\text { Islamic New Year / } \\
\text { Hijriyyah New Year } \\
\text { / Tabligh Akbar }\end{array}$ & $\begin{array}{l}\text { Oral and } \\
\text { Writing }\end{array}$ & $\begin{array}{l}\text { Worship } \\
\text { Facilities and } \\
\text { Infrastructure }\end{array}$ & $\begin{array}{l}\text { Media: Print, } \\
\text { Electronics and } \\
\text { Social }\end{array}$ \\
\hline 2. & $\begin{array}{l}\text { Commemoration of } \\
\text { the Prophet's } \\
\text { Birthday, / Tabligh } \\
\text { Akbar }\end{array}$ & $\begin{array}{l}\text { Oral and } \\
\text { Writing }\end{array}$ & $\begin{array}{l}\text { Worship } \\
\text { Facilities and } \\
\text { Infrastructure }\end{array}$ & $\begin{array}{l}\text { Media: Print, } \\
\text { Electronics and } \\
\text { Social }\end{array}$ \\
\hline 3. & $\begin{array}{l}\text { Commemoration of } \\
\text { Isra 'Mi'raj / Tabligh } \\
\text { Akbar }\end{array}$ & $\begin{array}{l}\text { Oral and } \\
\text { Writing }\end{array}$ & $\begin{array}{l}\text { Worship } \\
\text { Facilities and } \\
\text { Infrastructure }\end{array}$ & $\begin{array}{l}\text { Media: Print, } \\
\text { Electronics and } \\
\text { Social }\end{array}$ \\
\hline 4. & $\begin{array}{l}\text { Halal Bi Halal } \\
\text { Program and } \\
\text { Releasing Hajj / } \\
\text { Tabligh Akbar }\end{array}$ & $\begin{array}{l}\text { Oral and } \\
\text { Writing }\end{array}$ & $\begin{array}{l}\text { Worship } \\
\text { Facilities and } \\
\text { Infrastructure }\end{array}$ & $\begin{array}{l}\text { Media: Print, } \\
\text { Electronics and } \\
\text { Social }\end{array}$ \\
\hline 5. & $\begin{array}{l}\text { Community } \\
\text { Guidance and } \\
\text { Counseling "Anti } \\
\text { Drugs, Anti } \\
\text { Radicalism and } \\
\text { Terrorism" }\end{array}$ & $\begin{array}{l}\text { Oral and } \\
\text { Writing }\end{array}$ & $\begin{array}{l}\text { Facilities and } \\
\text { Infrastructure } \\
\text { Activities }\end{array}$ & $\begin{array}{l}\text { Media: Print, } \\
\text { Electronics and } \\
\text { Social }\end{array}$ \\
\hline 6. & $\begin{array}{l}\text { Guidance for } \\
\text { Women and } \\
\text { Children Prisoners, } \\
\text { Lectures and } \\
\text { Tutorials }\end{array}$ & $\begin{array}{l}\text { Oral and } \\
\text { Writing }\end{array}$ & $\begin{array}{l}\text { Facilities and } \\
\text { Infrastructure } \\
\text { Activities }\end{array}$ & $\begin{array}{l}\text { Media: Print, } \\
\text { Electronics and } \\
\text { Social }\end{array}$ \\
\hline 7. & $\begin{array}{l}\text { Community Service, } \\
\text { Guidance and } \\
\text { Counseling in } \\
\text { Nursing Homes / } \\
\text { Practical Worship } \\
\text { Guidance }\end{array}$ & $\begin{array}{l}\text { Oral and } \\
\text { Writing }\end{array}$ & $\begin{array}{l}\text { Facilities and } \\
\text { Infrastructure } \\
\text { Activities }\end{array}$ & $\begin{array}{l}\text { Media: Print, } \\
\text { Electronics and } \\
\text { Social }\end{array}$ \\
\hline 8. & $\begin{array}{l}\text { Health / Nutrition } \\
\text { Services, Guidance } \\
\text { and Counseling }\end{array}$ & $\begin{array}{l}\text { Oral and } \\
\text { Writing }\end{array}$ & $\begin{array}{l}\text { Facilities and } \\
\text { Infrastructure } \\
\text { Activities }\end{array}$ & $\begin{array}{l}\text { Media: Print, } \\
\text { Electronics and } \\
\text { Social }\end{array}$ \\
\hline 9. & $\begin{array}{l}\text { Prospective Bride } \\
\text { and Grooming } \\
\text { Course Sakinah } \\
\text { Family }\end{array}$ & $\begin{array}{l}\text { Oral and } \\
\text { Writing }\end{array}$ & $\begin{array}{l}\text { Facilities and } \\
\text { Infrastructure } \\
\text { Activities }\end{array}$ & $\begin{array}{l}\text { Media: Print, } \\
\text { Electronics and } \\
\text { Social }\end{array}$ \\
\hline
\end{tabular}

${ }^{12}$ Data Sources, Data Processed From BKMT Documentation of Riau Province, 2017. 


\begin{tabular}{|l|l|l|l|l|}
\hline 10. & $\begin{array}{l}\text { Home Industry } \\
\text { Education and } \\
\text { Training }\end{array}$ & $\begin{array}{l}\text { Oral and } \\
\text { Writing }\end{array}$ & $\begin{array}{l}\text { Facilities and } \\
\text { Infrastructure } \\
\text { Activities }\end{array}$ & $\begin{array}{l}\text { Media: Print, } \\
\text { Electronics and } \\
\text { Social }\end{array}$ \\
\hline
\end{tabular}

Because the use of media or communication aids has a very important role in the delivery of messages in the development of Islamic $D a^{\prime} w a h$, the selection of media or communication aids needs to get the attention of BKMT Regional Management of Riau Province.

\section{Conclusions}

Communication planning and management; (1) communication planning, contained in the program of $D a^{\prime} w a h$ and Issuance of BKMT Regional Management of Riau Province for the period 2012-2017, includes the objectives, targets and steps of activities, (2) communication management; communication management in the development of Islamic Da'wah of BKMT Regional Management of Riau Province can be traced from the activities program of Da'wah and Issuance of BKMT Regional Management of Riau Province for the 2012-2017 period, including planning for organizing, implementing and evaluating.

Methods and techniques communication: The communication methods used by BKMT are more dominant in informative communication, persuasive communication and educational communication as the most effective and most used method.

Communication model; (1) communicator, preachers who give propaganda material in every activity are preachers whose kafaah in their fields are selected and prioritized by the BKMT Management (2) messages, the contents of the message conveyed lead to a better life, with Aqidah, Sharia (Worship) material and morals. (3) Communicants / communication targets, are mothers who are members of the assembly in each area (4) media / communication aids, all types of media or assistive devices used, which include oral, written, religious facilities and infrastructure / activities, print media, electronic media and social media.

\section{References}

Abdullah, Ilmu Dakwah; Kajian Ontologi, Epistemologi, Aksiologi dan Aplikasi Dakwah, (Bandung : Ciptapustaka Media, 2015).

Abdurrahman, Oemi. Dasar-dasar Public Relations, (Bandung: Alumni, 2003).

Abidin, Djamaludin. Komunikasi dan Bahasa Dakwah, (Jakarta: Gema Insani Press, 2006).

Afandi, Bisri. Beberapa Percikan Jalan Dakwah, (Surabaya: Fakultas Dakwah IAIN Sunan Ampel, 2004).

Ahmad, Amrullah. Dakwah Islam dan Perubahan Sosial, (Yogyakarta: Primaduta, 2003).

Aloliliweri, Komunikasi Antar Pribadi, (Bandung: Citra Aditya Bakti, 1997).

Amin, H.M. Masyhur. Dekat Islam dan Pesan Moral (Yogyakarta: al- Amin Press, 1997),p. 79.

Anwar, H. Rosihan. Demi Dakwah, (Bandung: al-Ma'arif, 2006).

Arifin, H.M. Psikologi Dakwah; Suatu Pengantar Studi, ( Jakarta : Bumi Aksara, 2004).

Arifin,Anwar. Strategi Komunikasi, (Bandung : Amrico, 2005).

Arikunto, Soeharsimi. Prosedur Penelitian Suatu Pendekatan Praktek (Jakarta P.T. Rineka Cipta, 2002). 
Atsir, Izz al-Din Abd al-Karim ibn al-. Usdu al-Ghabah 'An Hayat al-Shahabah, (Beirut: Dar al-Fikr, tt) Juz I.

Bachtiar, Wardi. Metodologi Penelitian Ilmu Dakwah (Jakarta: Logos Wacana Ilmu, 2007).

Bakker dan Achmad Charis Zubar, Anton. Metodologi Penelitian Filsafat, (Yogyakarta : Kanisius, 2002).

Bukhari, Abu Abdullah Muhammad bin Isma'il bin Ibrahim bin al-Mughirah al-Jafari al-. Shaheh al-Bukahri, (Semarang : Toha Putra, 2003), Juz VI.

Burhanuddin, Jajat. Ulama Perempuan Indonesia, (Jakarta: Gramedia Putaka Utama, 2009).

Cangara, Hafied. Pengantar Ilmu Komunikasi, (Jakarta: PT. Raja Grafindo Persada, 2008).

-------,Perencanaan dan Strategi Komunikasi, (Jakarta: Raja Grafindo Persada,2013).

Efendy, Onong Uchajana. Spektrum Komunikasi, (Bandung: CV. Mandar Maju, 2002).

--------,Ilmu Komunikasi Teori dan Praktek, (Bandung : Remaja Rosame as above Karya, 2001).

--------,Dinamika Komunikasi, (Bandung: Remaja Rosame as above Karya, 2003).

Ensiklopedi Tokoh Indonesia - Biografi Tuty Alawiyah; http://www. TokohIndonesia.com. Accessed on thursday 14 October 2017.

Fadullah, Muhammad Husain. Uslub ad-Dakwah fi al-Quran (Metodologi Dakwah Dalam alQuran Pegangan Bagi Aktifis), Translated by Tarmana Ahmad Qasim, (Cet. I; Jakarta: Lentera, 1997).

Fatwa, Marsekah. Tafsir Dakwah (Surabaya: IAIN Sunan Ampel, 2008).

Fauziah, Amelia. Wacana Gerakan Perempuan Islam Indonesia, (Jakarta : Gramedia Pustaka Utama, 2009),

Ghazali, M. Buhri. Dakwah Komunikatif Membangun Kerangka Dasar Ilmu Komunikasi Dakwah (Jakarta: Pedoman Ilmu Jaya, 2007).

Gunadi, Y.S. Himpunan Istilah Komunikasi, (Jakarta : PT. Grasindo, 2008).

Gunarsa, Singgih Dirda. Pengantar Psikologi, (Jakarta: Mutiara, 2003).

Habib, M. Syafa'at. Buku Pedoman Dakwah, (Jakarta : Wijaya, 2001).

Hanbal, Abu Abdullah Ahmad ibn. Musnad Imam Ahmad, (Beirut : Dar al-Fikr, 1990), Juz I,.

Harahap, H. Syahrin. Islam dan Implementasi Pemberdayaan (Yogyakarta: Tiara Wacana Yogya, 2009).

Hasymi, A. Dustur Dakwah Menurut al-Quran (Jakarta: Bulan Bintang, 2007).

Hikmat, Harry. Strategi Pemberdayaan Masyarakat, (Bandung : Humaniora Utama Press, 2001).

Kholil, Syukur. Komunikasi Islam,( Citapustaka Media, 2007).

Shabbagh, Muhamrnad al-. Min Sifat al-Da'iyah (Kriteria Seorang dai), diterjemahkan oleh A.M. Basalamah (Jakarta: Gema Insani Press, 2001).

Shihab, M. Quraish. Wawasan al-Qur'an ;Tafsir Maudhu'iy Atas Pelbagai Persolan Umat, (Bandung : Mizan, 2006).

Siddiq, Syamsuri. Dakwah dan Teknik Berkhutbah, (Bandung : CV. al-Ma'arif, 2003).

Silalahi, Gabriel Amin. Metode Penelitian dan Study Kasus (Sidoarjo: CV. Citra Media, 2003).

Soekanto, Soejono. Sosiologi Suatu Pengantar, (Jakarta: Rajawali Pres, 2004).

---------,Penelitian Hukum Normatif, (Jakarta: Raja Grafindo, 2003).

Susanto, Phil Astrid. Komunikasi Dalam Teori dan Praktek, (Bandung : Bina Cipta, 1977).

Syallabi, Rauf. Al-Dakwah al Islamiyah Fi 'Ahdiha al-Makky, Manahijuha wa Ghoyatuha, (Kairo: Dar al-Manar, $\mathrm{tt}$ ).

Syukir, Asmuni. Dasar-dasar Strategi Dakwah Islam, (Surabaya: al-Ikhlas, 2003). 
Tim Penyusun Kamus Pusat, Kamus Besar Bahasa Indonesia, (Jakarta : Balai Pustaka, 2004). Widjojo, CM., Jhon Tondo. Komunikasi Pembangunan Masyarakat, (Surabaya : Sanggar Binatama, 2007).

Yakub, H. Hamzah. Publisistik Islam; Teknik Dakwah dan Leadership (Bandung: Diponegoro, 2007).

Yunus, Mahmud. Kamus Arab Indonesia, (Jakarta: Yayasan Penyelenggara Penterjemah/ Pentafsir al-Qur'an Depag RI, 1973).

Yusuf, Muhammad Khair Ramadhan. Min Khasa'is I'lam al-Islami, Peranan Media Informasi Islam Dalam Pengembangan Umat,diterjemahkan oleh Muhammad Abdul Hattar (Jakarta : Pustaka al-Kautsar, 2006).

Zahrah, Abu. al-Da'wah ila al-Islam, diterjemahkan oleh H. Ahmad Subandi dan Ahmad Supeno, (Bandung: Remaja Rosame as above Karya, 2004).

Zaidan, Abdul Karim. Ushul al-Dakwah, (Bagdad : Dar Umar al-Khattab, 1975).

Zakariya, Abu al-Husain Ahmad bin Faris bin. Mu'jam Maqayis al-Lughat, (Kairo: Musthafa al-Baby al-Halabiy, 2009), Juz II.

Zikri, Abu Bakar. al-Dakwah ila al-Islam, (Mesir: Maktabah Darul Arubah, tt). 